\title{
Comparison of live shrimp bait catch efficiency in single line fishery
}

\author{
Myungsung Koo', Ishizaki Munechika'2, Samkwang Cho', Bongseong Bae', Bongjin Cha ${ }^{1, *}$ \\ ${ }^{1}$ Fisheries Engineering Research Division, National Institute of Fisheries Science, Busan 46083, Korea \\ ${ }^{2}$ Faculty of Fisheries, Kagoshima University, Kagoshima 890-0056, Japan
}

\begin{abstract}
On the southern coast of South Korea, dark-banded rockfish, sea bass, and red seabream are caught by single-line fishing. In particular, red seabream and sea bass are caught in the Jeollanam-do region using gear with attached fishing hooks, such as longline and single-line gear, with live shrimp as bait. The objective of this study was to compare the catch efficiency of two types of live shrimp (naturally grown Shiba shrimp [Metapenaeus joyneri] and cultured whiteleg shrimp [Litopenaeus vannamei]) used as bait. The investigation included interviews, on-board surveys, and water tank experiments. Interviews were conducted with relevant parties to determine the preference for live shrimp as bait, and the results showed a greater preference for cultured whiteleg shrimp. Further, an on-board survey was conducted to compare catch efficiency between these two types of live shrimp bait for single-line fishing. The on-board investigations were conducted once or twice a month between June and October. In total, the amounts of fish caught using naturally grown Shiba shrimp and cultured whiteleg shrimp were 56 and 52, respectively. Of these, the numbers of sea bass, the primary target fish species, caught using naturally grown Shiba shrimp and cultured whiteleg shrimp were 43 and 40 , respectively. Thus, the results showed that there was almost no difference in the number of fish caught based on the bait used. However, according to a water tank experiment, cultured whiteleg shrimp survived longer than naturally grown Shiba shrimp.
\end{abstract}

Keywords: Single line, Live shrimp, Bait, Catch efficiency, Gill net

\section{Introduction}

A single-line fishery refers to a type of fishery in which fishing gear composed of a fishing line and hook is used to lure a marine animal with a bait or lure and catch it with a hook. Generally, this fishing gear is simple and does not require a large investment, and fisheries are recognized even if their amount of catch is low. A single-line fishery off the coast of South Korea catches blackhead seabream (Acanthopagrus schlegelii), dark-banded rockfish (Sebastes inermis), sea bass (Latelolabrax japonicus), and yellowtail (Seriola quinqueradiata) (NFRDI, 2008). The bait used in a single-line fishery may vary depending on the region and target species, of which live shrimp is used as a bait for some species. Sea bass, the primary target species of

\footnotetext{
Received: Jul 30, 2021 Revised: Sep 10, 2021 Accepted: Oct 27, 2021

*Corresponding author: Bongjin Cha

Fisheries Engineering Research Division, National Institute of Fisheries Science, Busan 46083, Korea

Tel: +82-51-720-2570, Fax: +82-51-720-2586, E-mail: holdu@korea.kr
}

This is an Open Access article distributed under the terms of the Creative Commons Attribution Non-Commercial License (http://creativecommons.org/licenses/by$\mathrm{nc} / 4.0 /$ ) which permits unrestricted non-commercial use, distribution, and reproduction in any medium, provided the original work is properly cited.

Copyright $\odot 2021$ The Korean Society of Fisheries and Aquatic Science 
this fishery, belongs to the order Perciformes, Moronidae family (NFRDI, 2004), which is found mostly in the western coasts of the North Pacific Ocean, including the coasts of South Korea, Japan, China, and Taiwan, the waters surrounding Japan, and the East China Sea (Huh et al., 2009; Kim et al., 1997; Yamada et al., 1986; Yamada et al., 2007). They can grow up to a body length of $104 \mathrm{~cm}$ and a weight of 8,700 $\mathrm{g}$ (IGFA, 2001).

Single-line fisheries require combo fishing licenses, which causes the selection of species and catch efficiency to vary depending on the bait. Fishing techniques vary significantly based on the composition of fishing gear, fishery method, target species, fishing ground, region, and individual (Kaneda, 2005).

Sea bass caught by combo fishing reached an annual production of 485.7 tons in the past 10 years (2011-2020). During this period, the highest production was 710 tons in 2018, and the lowest production was 358 tons in 2017 (KOSIS, 2021).

Previous studies related to single-line fishing include the behavior of giant Pacific octopus and hook design (Park et al., 2004); longline hook selectivity for red tilefish (Yamashita et al., 2009); the effects of inducing feeding behavior in red seabream via a visual stimulus with a moving object (Koo et al., 2013); and tail beating periodicity of hooked carp (Ko \& Kim, 1982). However, there have been no studies concerning catch efficiency according to the type of live shrimp bait used.

According to the interview results, most fishers prefer cultured whiteleg shrimp to naturally grown Shiba shrimp. Their reason for this preference was the difficulty in purchasing naturally grown Shiba shrimp. Another reason was that naturally grown Shiba shrimp cannot be supplied during the period when shrimp net fishing is banned, whereas cultured whiteleg shrimp are continually available. Although most fishers preferred cultured whiteleg shrimp, some stated that cultured whiteleg shrimp is difficult to use as bait during the winter because it is too large, and that they were also too costly. However, sea bass, the main target species in this study, was caught as adult fish only up to the middle of October, and thus, some opined that sea bass fishing is unrelated to the period when the size of cultured whiteleg shrimp increases.

Therefore, the objective of this study was to compare the catch efficiency of two types of live shrimp (naturally grown Shiba shrimp [Metapenaeus joyneri] and cultured whiteleg shrimp [Litopenaeus vannamei]) used as bait. The investigation included interviews, on-board surveys, and water tank experiments. Specifically, this study evaluated fishing status, such as fishing period, fishing grounds, bait used, bait preference, and species caught by fishing period, and catch by type of bait according to on-board surveys and water tank experiments.

\section{Materials and Methods}

\section{Interviews}

To identify the status of single-line fisheries in the Jeollanam-do region, interviews were conducted with fishers and relevant public officials. These interviews were conducted on-site at the Jeollanam-do Office (January 17, 2018), Wando-gun Fishing Vessel Association (February 19, 2018), and Gyema fishing village community in Yeonggwang-gun (March 21, 2018). The concepts investigated included the number of fishing vessels by region, fishing status, and usage status of live shrimp bait.

\section{Test gear}

The single-line fishing gear currently used by fishers (Fig. 1) was used in the catch efficiency investigation. The accessories used for the test gear include the main line, branch line, fishing hook,

Main line: 6 Braid PE Line $(0.42 \mathrm{~mm})$

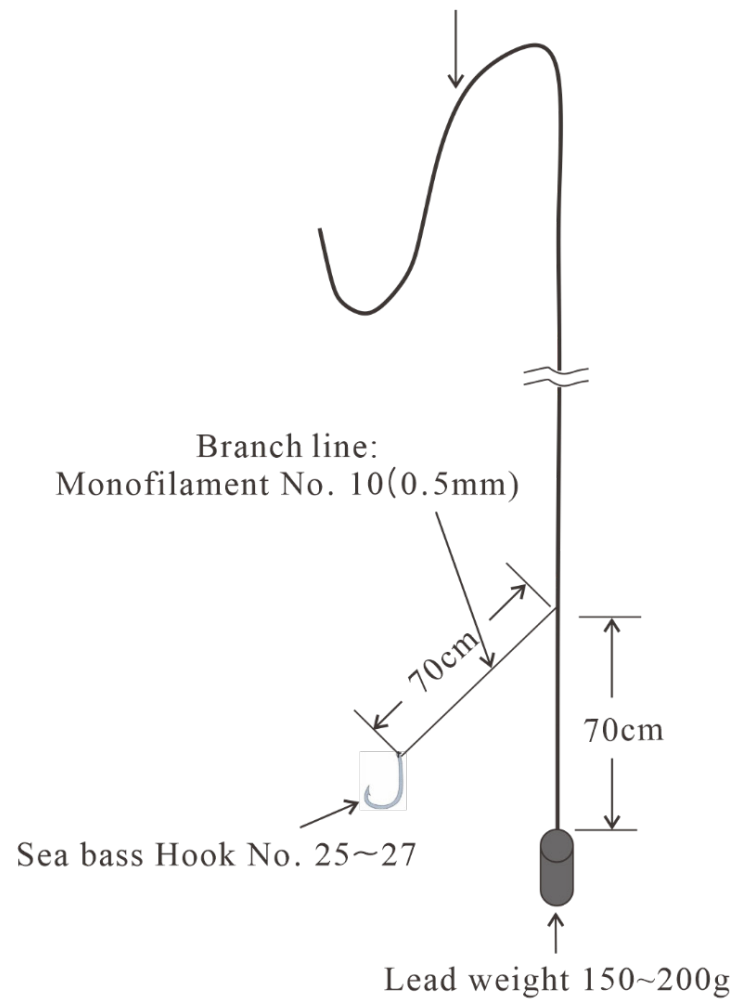

Fig. 1. Diagram of single-line fishing gear used in catch efficiency investigation. 
swivel, and lead sinker. In particular, a \#6 braided line (diameter $0.42 \mathrm{~mm}$ ) was used as the main line and a single \#25-27 sea bass hook was used as the fishing hook. Further, a \#10 sight line (diameter $0.5 \mathrm{~mm}$ ) was used as the branch line, which was 70 $\mathrm{cm}$ long and located $70 \mathrm{~cm}$ from the lead sinker. Varying shapes of lead sinkers, weighing 150-200 g, were attached to the bottom part of the single-line fishing gear. The weight and shape of the lead sinker changed according to the current during actual fishing. Note that it is common to lose the branch line or lead sinker during fishing, and several extras were prepared in case of such loss. Further, the single line was connected to a fishing pole, and a reel was used to release or wind the line.

\section{On-board surveys of catch efficiency}

Based on the interview findings, surveys of catch efficiency were conducted on board Daegwang \#2 (1.71 ton, 200 hp outboard), which travels in and out of Gyema Port in Yeonggwang-gun, Jeollanam-do. On-board surveys were conducted once or twice a month during the main fishing season, which extends from the end of June to the middle of October.

As listed in Table 1, a total of six catch efficiency surveys were conducted with naturally grown Shiba shrimp and cultured whiteleg shrimp prepared as bait. The crew consisted of 3-4 members, including the captain, and 2-3 researchers were also on board for the survey. Prior to departure, cultured whiteleg shrimp were supplied to the vessel by a shrimp farmer, while naturally grown Shiba shrimp were caught before sunrise. The water temperature was measured with a seawater thermometer (HOBO UA-002-08, Onset, Bourne, MA, USA) once after arriving at the fishing ground and again before starting the experiment. The water depth was measured at the bottom of the sea, where fishing gear was installed.

The track of the vessel used for the on-board surveys was recorded using GPS (Fig. 2). Between June and September, the vessel departed from Gyema Port and fished in waters $1 \mathrm{~h}$ to the south, reaching as far as Songido. Meanwhile, in October, fishing activities took place near Gupo Port in the north because of fluctuations in water temperature.

Live bait was used for the catch efficiency surveys. Different types of bait were kept in separate live fish tanks to prevent them from mixing. Upon arrival at the fishing ground, a researcher handed a crewmember one live shrimp at a time without informing them of the shrimp type. The live shrimp used in the surveys were selected based on the bait size preferred by

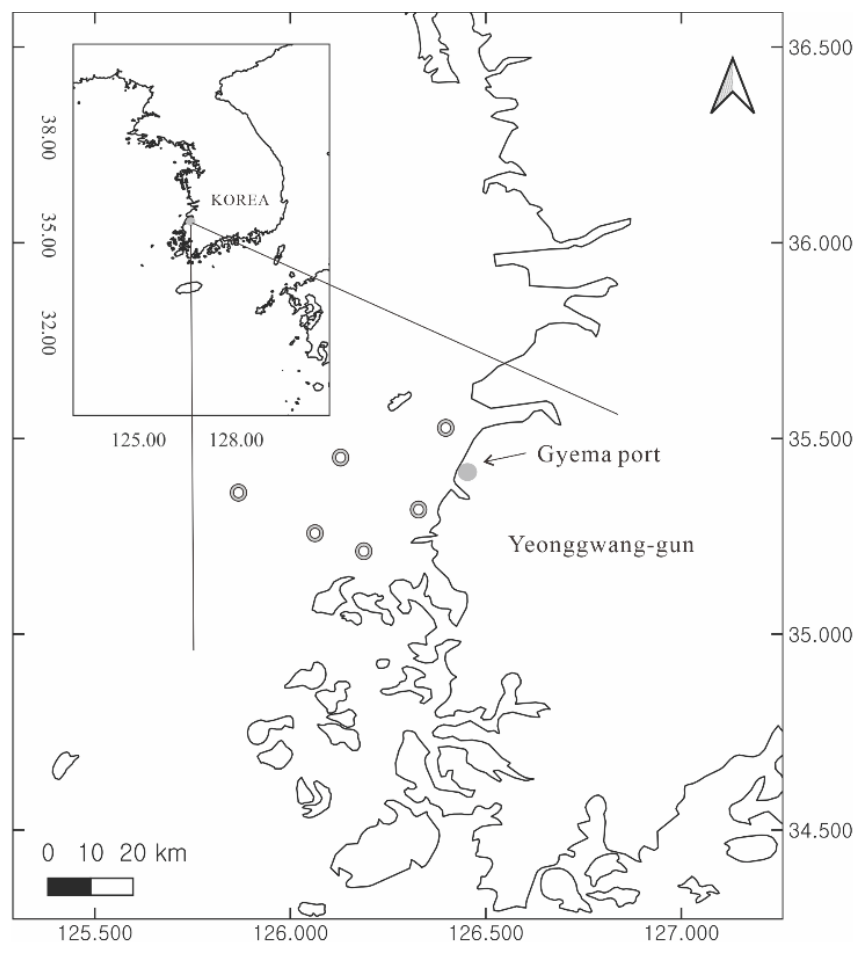

Fig. 2. Catch efficiency survey places of single-line fishing for catch efficiency surveys.

Table 1. Date, bait used, and water temperature for survey of single-line catch efficiency in Jeollanam-do region

\begin{tabular}{lllll}
\hline Date & Amount of bait used & & Number of crew members & Water temperature \\
\cline { 2 - 3 } & Naturally grown Shiba shrimp & Cultured whiteleg shrimp & & $22.6^{\circ} \mathrm{C}$ \\
\hline June 29 & 32 & $1 \mathrm{~kg}$ & 4 & $27.2^{\circ} \mathrm{C}$ \\
July 23 & 70 & $2 \mathrm{~kg}$ & 3 & $28.5^{\circ} \mathrm{C}$ \\
August 6 & 57 & $2 \mathrm{~kg}$ & 4 & $30.3^{\circ} \mathrm{C}$ \\
August 10 & 98 & $2 \mathrm{~kg}$ & 3 & $23.0^{\circ} \mathrm{C}$ \\
September 20 & 217 & $2 \mathrm{~kg}$ & 3 & $18.4^{\circ} \mathrm{C}$ \\
October 18 & 65 & $2 \mathrm{~kg}$ & 3 & 3 \\
\hline
\end{tabular}


actual fishers. In particular, the body lengths were approximately $12 \mathrm{~cm}$, and the range of cephalothorax length was $3.2-4.7 \mathrm{~cm}$ for naturally grown Shiba shrimp and 3.4-4.6 cm for cultured whiteleg shrimp.

Each time a fish was caught, it was brought on-board. After removing the hook, the length was measured using a tape measure (5 m, Komelon, Busan, Korea) and the weight was measured with a hanging hand scale (resolution $10 \mathrm{~g}$, Cas, Yangju, Korea) before it was placed in the live fish tank. Fish species, length, and weight were recorded in a survey log, as well as information regarding the type of bait used and the crewmember who caught the fish.

The dimensions of the water tank used in the experiment were $250 \mathrm{~cm}$ long, $120 \mathrm{~cm}$ wide, and $80 \mathrm{~cm}$ high, with a water depth of $75 \mathrm{~cm}$ and a water temperature of $19.5^{\circ} \mathrm{C}$. The experiment was recorded using a video camera (Hero6, Gopro, San Mateo, CA, USA) placed above the water tank. To avoid influencing the behavior of the test shrimp, the experimental process was monitored at a separate location via a monitor connected wirelessly to the video camera. The seawater continuously circulated naturally during the experiment. The illuminance during the experiment was that of the natural light coming in through the window.

The average body length, cephalothorax length, and weight of 30 naturally grown Shiba shrimps used in the experiment were $10.3 \mathrm{~cm}, 2.5 \mathrm{~cm}$, and $5.9 \mathrm{~g}$, respectively, while those for 30 cultured whiteleg shrimps were $16.2 \mathrm{~cm}, 3.4 \mathrm{~cm}$, and $28.7 \mathrm{~g}$, respectively.

\section{Results}

\section{Fishing status}

Fisheries using live shrimp bait in the Jeollanam-do region employ both longline and single-line fishing. Specifically, the number of vessels involved in longline fishing was 314, of which there were - 50 in Yeosu, 21 in Mokpo, 100 in Goheung-gun, 5 in Gangjin-gul, 6 in Hampyeong-gun, 13 in Yeonggwang-gun, and 119 in Wando. Meanwhile, the number of vessels involved in single-line fishing was 11 , of which there was 1 vessel in Wando and 10 vessels in Yeonggwang-gun. The target species caught by these vessels include sea bass, Chinese drum (Miichthys miiuy), red seabream, and various other fish. The live shrimp used as bait were obtained via shrimp net fishing and were purchased from shrimp growers. The annual usage ranged from $200 \mathrm{~kg} /$ vessel (Yeosu) to 1,500 kg/vessel (Goheung), while the purchasing cost (based on cultured shrimp) was 15,000 won/kg (Wando) to 30,000 won/kg (Goheung). Regional differences in the route and price of purchase occurred because of the distance from the shrimp farm, making it difficult to calculate the cost associated with shrimp net fishing.

To determine the preference for live shrimp bait among fishers, surveys conducted by the Department of Marine Fisheries Resources of Jeollanam-do Office were obtained. The preference was $100 \%$ cultured shrimp in Mokpo, Yeosu, and Wando-gun, 5\% naturally grown shrimp and 95\% cultured shrimp in Goheung-gun, and 10\% naturally grown shrimp and 90\% cultured shrimp in Gangjin-gun. These results indicate that most regions in Jeollanam-do prefer cultured live shrimp bait. The reason for not preferring naturally grown shrimp was the difficulty in purchasing them. Further, the reasons for preferring culture shrimp were long survival periods, similar catch efficiency, and availability of stable supply even during seasons when shrimp net fishing is banned.

Longline gear was left in the water for 2-3 days, and depending on the tide, the line was hauled in within $1 \mathrm{~h}$ of being cast. The number of fishing hooks used varied from 100 /basket (prawn) to 130 /basket (white leg shrimp). The number of baskets used was approximately 30 /day, and the time required for the longline catch was 5-6 h.

In Yeonggwang-gun, cultured whiteleg shrimp were purchased or naturally grown Shiba shrimp were caught directly via trammel net fishing for use as single-line fishing bait. The price of cultured whiteleg shrimp was 15,000-25,000 won/kg, and the shrimp were delivered to the vessels by a live-fish truck. The live shrimp used as bait were used at a rate of up to $1-1.5 \mathrm{~kg} /$ person each day (150 shrimp/kg), and the main target species were sea bass and Chinese drum.

\section{Amount of catch by type of bait}

During the first catch efficiency survey, no fish were caught. During the second survey (July 23), a total of 23 fish were caught, all of which were sea bass. With respect to catch by bait, 11 fish were caught using 29 naturally grown Shiba shrimp and 12 fish were caught using 28 cultured whiteleg shrimps.

During the third survey (August 6), a total of 16 fish were caught, consisting of ten Korean rockfish (Sebastes schlegelii), four sea bass, one bartail flathead (Platycephalus indicus), and one puffer fish (Tetraodontidae). With respect to catch by bait, five fish were caught using 31 naturally grown Shiba shrimp and ten fish were caught using 35 cultured whiteleg shrimps. 
During the fourth survey (August 10), a total of 21 fish were caught, including nine sea bass, nine bartail flatheads, one olive flounder (Paralichthys olivaceus), and one Korean rockfish. With respect to catch by bait, 13 fish were caught using 38 naturally grown Shiba shrimp, and 8 fish were caught using 36 cultured whiteleg shrimps.

During the fifth survey (September 20), a total of 45 fish were caught, including 44 sea bass and one Chinese drum. With respect to catch by bait, 24 fish were caught using 42 naturally grown Shiba shrimp and 21 fish were caught using 43 cultured whiteleg shrimps.

Finally, during the sixth survey (October 18), three fish were caught, all of which were sea bass. With respect to catch by bait, two fish were caught using 21 naturally grown Shiba shrimp and one fish was caught using 22 cultured whiteleg shrimps.

Overall, a total of 108 fish were caught during six rounds of the survey. With respect to the species, sea bass accounted for the highest number at83 (76.9\%), followed by Korean rockfish (n $=11 \%, 10.2 \%)$, bartail flathead $(\mathrm{n}=10 \%, 9.3 \%)$, Chinese drum $(n=2 \%, 1.9 \%)$, and puffer fish and olive flounder $(n=1 \%, 0.9 \%$ each). A total of 56 fish (51.9\%) were caught using naturally grown Shiba shrimp, including 43 sea bass (76.8\%), six bartail flathead (10.7\%), five Korean rockfish (8.9\%), and two Chinese drum (3.6\%). Conversely, a total of 52 fish (48.1\%) were caught using cultured whiteleg shrimp, including 40 sea bass (76.9\%), six Korean rockfish (11.5), four bartail flathead (7.7\%), one puffer fish (1.9\%), and one olive flounder (1.9\%).

Fig. 3 shows the distribution of the body length and weight of the sea bass caught. The average body length was $57.3 \mathrm{~cm}$, and the average weight was $1,820 \mathrm{~g}$. Meanwhile, the average body length and weight values of bartail flathead were $38.2 \mathrm{~cm}$ and $485 \mathrm{~g}$, respectively, those of the Korean rock fish were 25.5 $\mathrm{cm}$ and $645 \mathrm{~g}$, respectively, those of the Chinese drum were 46.5 $\mathrm{cm}$ and $880 \mathrm{~g}$, respectively, those of the puffer fish were $13 \mathrm{~cm}$ and $30 \mathrm{~g}$, respectively, and those of the olive flounder were 49 $\mathrm{cm}$ and $680 \mathrm{~g}$, respectively.

Table 2 summarizes the combined sea bass results, which was the target species for the catch efficiency survey. Overall, the
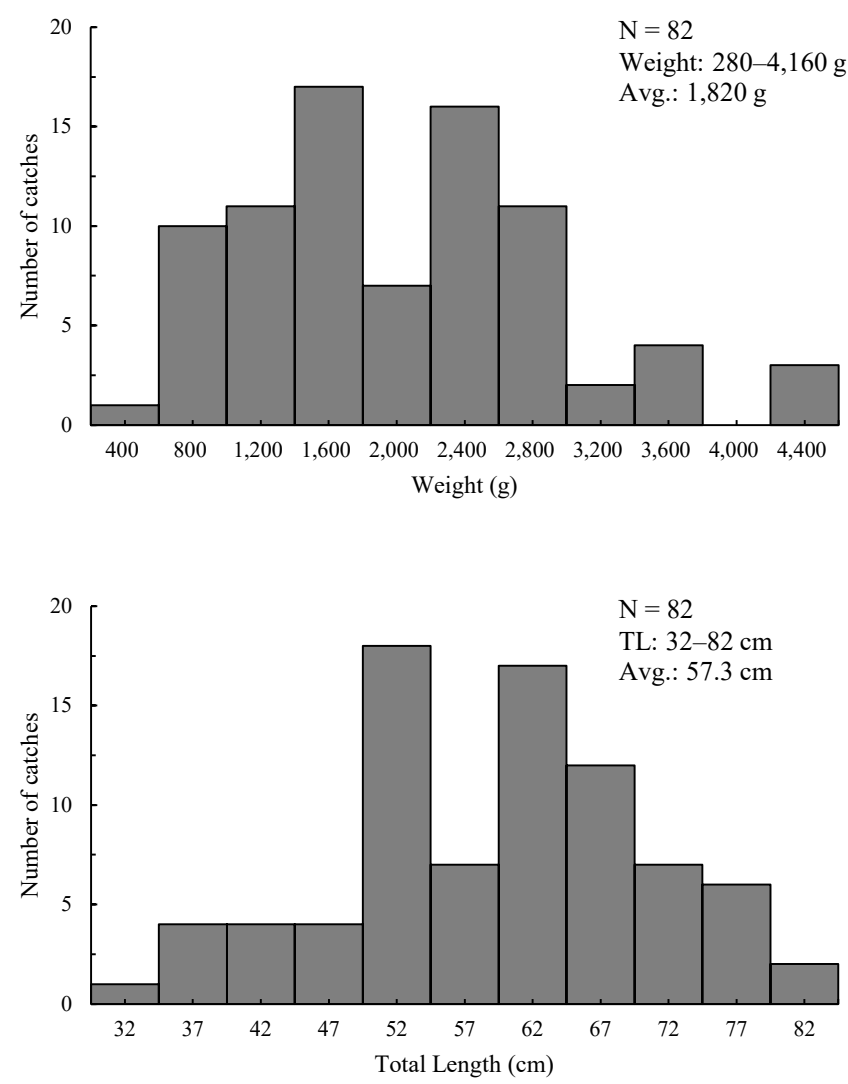

Fig. 3. Distribution of body length and weight of sea bass caught.

Table 2. Number and weight of sea bass caught by test fishing gear by date

\begin{tabular}{|c|c|c|c|c|}
\hline \multirow[t]{2}{*}{ Date } & \multicolumn{2}{|l|}{ Naturally grown Shiba shrimp } & \multicolumn{2}{|l|}{ Cultured whiteleg shrimp } \\
\hline & Number of sea bass caught & Total weight (g) & Number of sea bass caught & Total weight (g) \\
\hline July 23 & 11 & 17,220 & 12 & 14,610 \\
\hline August 6 & 2 & 2,200 & 2 & 2,300 \\
\hline August 10 & 5 & 6,310 & 4 & 5,740 \\
\hline September 20 & 23 & 47,590 & 21 & 48,430 \\
\hline October 18 & 2 & 2,400 & 1 & 1,120 \\
\hline Total & 43 & 75,720 & 40 & 72,200 \\
\hline Average & 8.6 & 15,144 & 8.0 & 14,440 \\
\hline
\end{tabular}


fish were caught using 43 naturally grown Shiba shrimp and 40 cultured whiteleg shrimp. The average weights of the sea bass caught using naturally grown Shiba shrimp and cultured whiteleg shrimp were $1,720 \mathrm{~g}$ and $1,860 \mathrm{~g}$, respectively. A paired $t$-test on catch efficiency between naturally grown Shiba shrimp and cultured whiteleg shrimp revealed no significant difference $(p>0.05)$.

\section{Discussion}

In the catch surveys using a single-line fishing vessel, naturally grown Shiba shrimp caught using trammel nets and cultured whiteleg shrimp were used as bait. Single-line fishing was conducted by actual fishers, during which the live shrimp bait was provided to the fishers by a researcher without revealing the type of bait. Among the fish caught, sea bass accounted for the majority, while Korean rockfish, bartail flathead, and other fish were also caught. The survey results showed almost no difference in the number of fish caught according to the type of bait. Actual fishers were also unable to differentiate based on the outer appearance of the live shrimp. Based on the findings from the on-board surveys, it was determined that there was almost no difference in catch efficiency between naturally grown Shiba shrimp and cultured whiteleg shrimp.

According to previous paper (Koo et al., 2013), movement and smell of bait affect the behavior of the target fish behavior. But this experiment verified only the survival time of the bait alone, not the response of the fish to the bait. A water tank experiment was also conducted to evaluate the survival period of live shrimp used as bait. Overall, the cultured whiteleg shrimp showed longer survival in both natural states and with the fishing hook in the mouth. This result could be another reason why fishers prefer cultured whiteleg shrimp. The fishers stated that they typically purchase sufficient cultured whiteleg shrimp for 2-3 days of use, rather than dealing with the burden of receiving a daily delivery of naturally grown Shiba shrimp by a livefish truck. They also mentioned that shrimp become less active after 2-3 days, which could cause a decline in catch efficiency. The water tank experiment results also confirmed that live shrimp became less active over time, which is consistent with the crewmember statements mentioned.

\section{Competing interests}

No potential conflict of interest relevant to this article was reported.

\section{Funding sources}

This research was a part of the project titled the 'Development of standardization technologies for marine and fishery industry equipment (20210044)', which is funded by the Ministry of Ocean and Fisheries, Korea.

\section{Acknowledgements}

Not applicable.

\section{Availability of data and materials}

Not applicable.

\section{Ethics approval and consent to participate}

This article does not require IRB/IACUC approval because there are no human and animal participants.

\section{ORCID}

Myungsung Koo

https://orcid.org/0000-0002-2137-4883

Munechika Ishizaki https://orcid.org/0000-0002-9471-4113

Samkwang Cho https://orcid.org/0000-0001-8461-4234

Bongseong Bae https://orcid.org/0000-0002-7602-985X

Bongjin Cha

https://orcid.org/0000-0002-3603-8225

\section{References}

Huh SH, Park JM, Park SC, Jeong D, Park CI, Baeck GW. Feeding habits of Lateolabrax japonicus in the coastal waters off Dolsan-do, Yeosu. Korean J Ichthyol. 2009;21:23-7.

International Game Fish Association [IGFA]. Database of IGFA angling records until 2001. Fort Lauderdale, FL: IGFA; 2001.

Kaneda, Y. Fisheries and fishing methods of Japan. Tokyo, Japan: Seizando Shoten; 2005. p. 100-37.

Kim CH, Jun JC. Provisional classification of temperate sea bass, the genus Lateolabrax (Pisces: Moronidae) from Korea. Korean J Ichthyol. 1997;9:108-13.

Ko KS, Kim YH. The jerking force by hooked carp and its periodicity with the tail beat. Bull Korean Fish Soc. 1982;15:226-32.

Koo MS, Ishizaki M, Kim SJ, Fuwa S. Inducing effect of visual stimulus for moving targets in red sea bream Pagrus major. Nippon Suisan Gakkaishi. 2013;79:158-65.

Korean Statistical Information Service [KOSIS]. Fishery production survey [Internet]. 2021 [cited 2021 July 2]. Available from: http://https://kosis.kr/statisticsList/statisticsListIndex. 
do?menuId=M_01_01\&vwcd=MT_ZTITLE\&parmTabId=M _01_01\&outLink=Y\&entrType=\#content-group

National Fisheries Research \& Development Institute [NFRDI]. Commercial fishes of the coastal and offshore waters in Korea. Busan, Korea: Hangul Press; 2004. p. 1-333.

National Fisheries Research \& Development Institute [NFRDI]. Fishing gear of Korea. Busan, Korea: Hangul Graphics; 2008. p. 1-579.

Park SW, Lee JW, Yang YS, Seo DO. A study on behaviour of giant Pacific octopus, Parotopus dofleini to single line hook for hook design. J Korean Soc Fish Ocean Technol. 2004;40:1-8.

Yamashita H, Shiode D, Tokai T. Longline hook selectivity for red tilefish Branchiostegus japonicus in the East China Sea. Fish Sci. 2009;75:863-74.

Yamada U. Fishes of the East China Sea and the Yellow Sea. Seikai Reg Fish Res Lab. 1986:68-9.

Yamada U, Tokimura M, Horikawa H, Nakabo T. Fishes and fisheries of the East China and Yellow Seas. Hadano, Japan: Tokai University Press; 2007. p. 745-53. 